\title{
Review Article \\ Research Progress of Nitrite Corrosion Inhibitor in Concrete
}

\author{
Yilin Song, Junzhe Liu $\mathbb{D}$, Hui Wang, and Haibin Shu \\ Faculty of Architectural, Civil Engineering and Environment, Ningbo University, Ningbo 315211, China \\ Correspondence should be addressed to Junzhe Liu; liujunzhe@nbu.edu.cn
}

Received 23 February 2019; Revised 25 April 2019; Accepted 7 June 2019; Published 24 July 2019

Academic Editor: Francisco Javier Perez Trujillo

Copyright (C) 2019 Yilin Song et al. This is an open access article distributed under the Creative Commons Attribution License, which permits unrestricted use, distribution, and reproduction in any medium, provided the original work is properly cited.

\begin{abstract}
Nitrite inhibitor is a kind of most effective inhibitory corrosion additive used in reinforced concrete. This paper expounded the inhibiting mechanism and physical property of nitrite in concrete. Moreover, the recent progress and application condition at home and abroad were summarized. Meanwhile, corresponding methods for detecting nitrite ion concentration is proposed. Additionally, the inhibition practice on corrosion protection of reinforcing bar in concrete was presented. The long-term inhibiting effectiveness of nitrite ion in concrete when the $\mathrm{n}\left(\mathrm{NO}_{2}^{-}\right) / \mathrm{n}\left(\mathrm{Cl}^{-}\right)$ratios were above the threshold values in concrete was obtained. Finally it is confirmed that critical molar ratio of $\mathrm{n}\left(\mathrm{NO}_{2}{ }^{-}\right) / \mathrm{n}\left(\mathrm{Cl}^{-}\right)$increased with differential nitrite ion concentration, higher cathode, and anode area ratio in steel bar.
\end{abstract}

\section{Introduction}

Typically, the hydroxide ions contained in concrete pore solution make the concrete $\mathrm{pH}$ above 12.0. In the alkaline environment, the surface of the steel bar is easy to form a passivation film of $20 \AA$ to $60 \AA$ thick, which acts as a barrier against the intrusion of aggressive species, providing chemical and physical protection to the embedded rebar $[1,2]$. Chloride salt and carbonation can easily destroy the passivation film and cause the corrosion of steel bars. Thus, in order to address the issue of steel corrosion in concrete, adding corrosion inhibitors into concrete has been frequently used, which is considered as an effective and economical method to avoid or delay the corrosion of reinforced concrete structures.

Concrete mixed with nitrite corrosion inhibitor is used to protect the steel in concrete. There are plenty of reports of use of this method at home and abroad [3-8]. Nitrite is the best corrosion inhibitor. It is the one used most widely and in the largest quantities. Nitrite corrosion inhibitor can delay the failure time of the passivation film and slow down the corrosion rate of the steel bar in the concrete $[9,10]$. After measuring the potential in the reinforced concrete structures, incorporating dozens of steel bar corrosion inhibitors such as phosphate, zinc oxide, gluconate, and nitrite commonly used in engineering, Gonzalez et al. [11] considered that the calcium nitrite has the best corrosion resistance. Berke et al. [12] also agreed that the most widely used corrosion inhibiting admixture is calcium nitrite, due to its excellent inhibitor properties and its benign effect on concrete properties. The corrosion inhibitor with nitrite as the main component has been used in thousands of parking buildings, offshore platforms, and highways in Japan, Europe, and other countries. Chinese "Technical Standard for the Use of Reinforced Concrete Corrosion Preventers" (YB/T923198) is also based on calcium nitrite. The RI-1 type inhibitor developed by the National Metallurgical Building Research Institute has been utilized in hundreds of projects around the world. Generally, it can be seen the corrosion inhibitors used in reinforced concrete projects are still dominated by nitrite components.

\section{Mechanism of Nitrite Corrosion Inhibitor}

As an anodic type steel bar corrosion inhibitor, nitrite forms a dense passivation film by oxidizing the iron atoms on the surface of the steel bar, inhibiting the anodic reaction of the steel bar surface. The mechanism of the corrosion inhibition in reinforced concrete is that the electrochemical reaction between $\mathrm{NO}_{2}{ }^{-}$and $\mathrm{Fe}^{2+}$ forms a $\mathrm{Fe}_{2} \mathrm{O}_{3}$ passivation film on the surface of the steel which can slow down the steel corrosion by 
preventing the loss of electrons after the iron atoms continue to dissolve.

$$
\begin{gathered}
2 \mathrm{Fe}^{2+}+2 \mathrm{OH}^{-}+2 \mathrm{NO}_{2}^{-}=2 \mathrm{NO}+\mathrm{Fe}_{2} \mathrm{O}_{3}+\mathrm{H}_{2} \mathrm{O} \\
\mathrm{Fe}^{2+}+\mathrm{OH}^{-}+\mathrm{NO}_{2}^{-}=\mathrm{NO}+\gamma-\mathrm{FeOOH}
\end{gathered}
$$

When concrete contains a high concentration of $\mathrm{NO}_{2}{ }^{-}$, chemical reactions of (1)(2) occur to suppress the corrosion reaction and protect the steel bars. When the nitrite ion concentration is low, the surface of the steel bar is unable to form a sufficient passivation film, so the rust inhibiting effect is weakened or disappeared. Nitrite is an anodic passivation film type, which can inhibit the micro-corrosion points in the passivation film into stable pitting. What is more, nitrite does not change the crystal structures and electronic properties of the passivation film; that is, the passivation film is still amorphous n-type semiconductor. The phase film accelerates the growth rate of the film, increases the surface $\gamma$-FeOOH content of the passivation film, improves the surface of the passivation film, makes it more flat, and has a significant inhibitory effect on macro-cell corrosion [13-16].

\section{General Characteristics of Nitrite Corrosion Inhibitor}

Nitrite species have a great impact on the setting time of cement paste, therefore, limiting the application of some nitrite corrosion inhibitors in concrete engineering. The results show the cement paste with a water-cement ratio of 0.3 will produce rapid setting when the content of calcium nitrite or magnesium nitrite is $4 \%$; rapid setting will occur when the amount of potassium nitrite is $2 \%$; lithium nitrite, sodium nitrite, and bismuth nitrite can reach 10\% [17]. On the other hand, sodium nitrite accelerates the occurrence of alkali-aggregate reaction by increasing alkali content in concrete pore solution; lithium nitrite not only has good rust resistance, but also inhibits the occurrence of alkali-aggregate reaction $[18,19]$. Calcium nitrite has low price and excellent rust resistance effect and has a certain early strength effect, but it shortens the setting time and increases the shrinkage deformation. [20].

\section{Corrosion Inhibition of Nitrite Corrosion Inhibitor}

4.1. Corrosion Inhibition in Chloride-Containing Concrete. Recently, nitrite corrosion inhibitors are often used in chloride-containing concrete. "The Technical Specification for the Application of Concrete Admixture" (GB50119-2013) stipulates that only when the molar ratio of nitrite to chloride is higher than a certain proportion can the effect of steel bar corrosion inhibition be guaranteed. The following factors will affect the critical molar ratio of $\mathrm{n}\left(\mathrm{NO}_{2}{ }^{-}\right) / \mathrm{n}\left(\mathrm{Cl}^{-}\right)$, such as chloride and nitrite species in concrete, curing conditions and period, corrosion environment, and evaluation methods. Liu et al [21] conduct accelerated steel corrosion test steel of reinforced concrete containing various quantities of calcium chloride and calcium nitrite and determine the critical molar
TABLE 1: Initial corrosion in relation to the $\mathrm{NaCl}$ concentration.

\begin{tabular}{lcccc}
\hline \multirow{2}{*}{ Parameter } & \multicolumn{4}{c}{$\mathrm{Ca}\left(\mathrm{NO}_{2}\right)_{2} / \mathrm{L} / \mathrm{m}^{3}$} \\
& 0 & 10 & 20 & 30 \\
\hline Time/d & 70 & 125 & 190 & 235 \\
NaCl Concentration/\% & 0.14 & 0.26 & 0.38 & 0.46 \\
\hline
\end{tabular}

ratio of $\mathrm{n}\left(\mathrm{NO}_{2}^{-}\right) / \mathrm{n}\left(\mathrm{Cl}^{-}\right)$by visual observations, anodic polarization, half-cell potentials, mass loss, and corroded area. It can be seen from Figures 1 and 2 that when the chloride ion concentration is constant, the corrosion effect of steel bars is more obvious with the increase of $\mathrm{n}\left(\mathrm{NO}_{2}{ }^{-}\right) / \mathrm{n}\left(\mathrm{Cl}^{-}\right)$; the higher the chloride ion concentration in concrete, the more severe the corrosion of the steel. The inhibiting effect of nitrite from reinforcement corrosion is not obvious and sometimes speeds up the macro-cell corrosion when critical value of $\mathrm{n}\left(\mathrm{NO}_{2}{ }^{-}\right) / \mathrm{n}\left(\mathrm{Cl}^{-}\right)$in reinforced concrete is less than 0.4. However, when the molar ratio reaches 0.8 , the pit erosion is basically eliminated, but it is not enough to completely inhibit the corrosion of the steel bar; when the molar ratio of $\mathrm{n}\left(\mathrm{NO}_{2}^{-}\right) / \mathrm{n}\left(\mathrm{Cl}^{-}\right)$is more than 1.2 , the corrosion of the steel bar can be completely suppressed.

Meanwhile, Berke et al. [12] presented a methodology for predicting an increased threshold for chloride induced corrosion, which can then be utilized with models that address the issue of chloride ingress into concrete over time, to predict service life extension through the use of calcium nitrite. And he found that calcium nitrite does not increase corrosion rates after chloride protection values are surpassed and in contrast often lowers them.

4.2. Corrosion Inhibition in Chloride Salt Erosion Concrete. When the chloride ions penetrate into concrete due to deicing salt, sea breeze, waves, etc., the preincorporation of nitrite can also effectively protect the steel bars. The concrete specimen containing calcium nitrite is immersed in a $3 \%$ aqueous solution of sodium chloride with the circulating environment of high temperature and high humidity $\left(60^{\circ} \mathrm{C}, 90 \%\right)$, low temperature, and low humidity $\left(20^{\circ} \mathrm{C}, 40 \%\right)$. Figure 3 shows measurement results of the chloride ion concentration in concrete and the potential of steel bar. Referring to Figure 3, calcium nitrite can effectively slow down the decline of potential and reduce the degree of corrosion. Table 1 shows that the greater the amount of calcium nitrite incorporation, the higher the $\mathrm{NaCl}$ concentration associated with initial corrosion. Be seen, when the chloride salt is infiltrated into the concrete from the external environment, the preincorporation nitrite corrosion inhibitor can prolong the corrosion start time of the steel bar and prolong the life of the reinforced concrete structure $[22,23]$.

4.3. Corrosion Inhibition in Carbonated Concrete. Carbonation can cause corrosion of steel in concrete, and the incorporation of nitrite into concrete can inhibit corrosion of steel. Wang [24] selects sodium nitrite to systematically study the effect of nitrite corrosion inhibitor on concrete and cement mortar carbonation performance by the method of rapid carbonation. The results show that adding $\mathrm{NaNO}_{2}$ can 


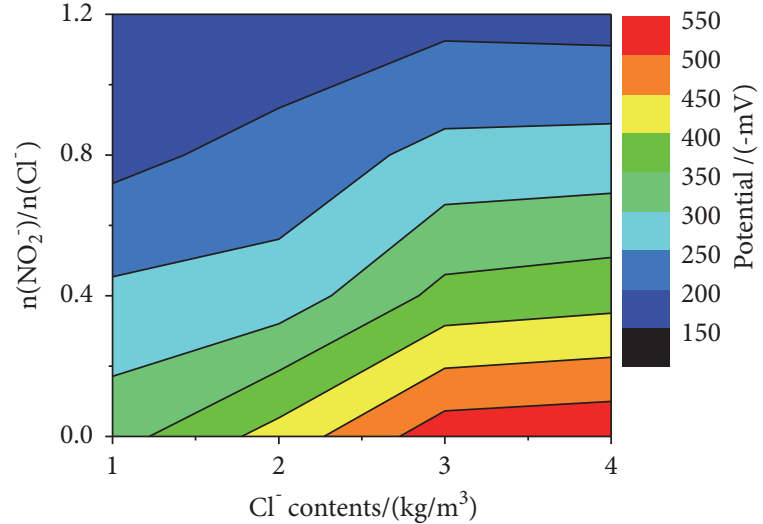

(a)

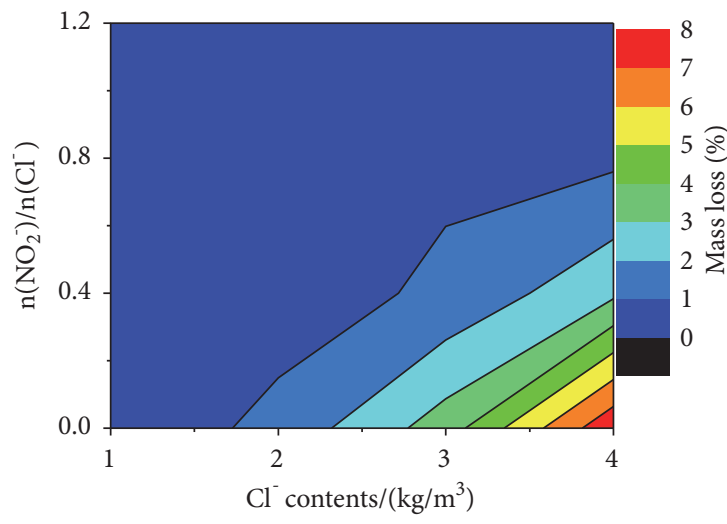

(c)

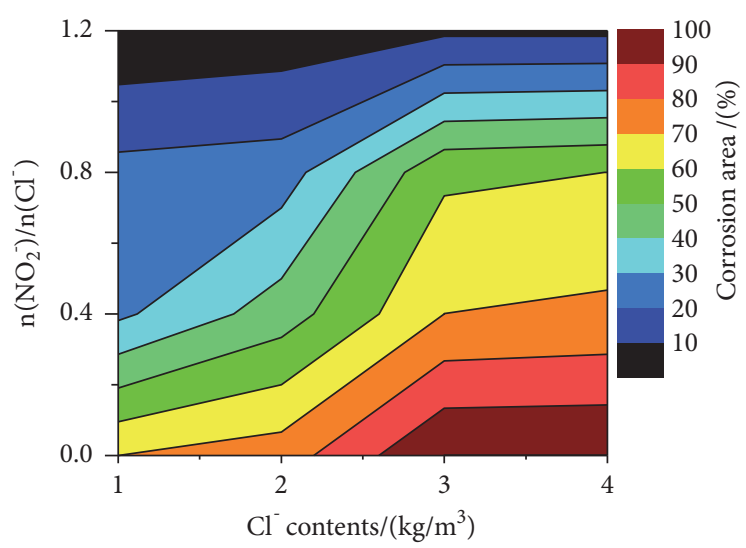

(b)

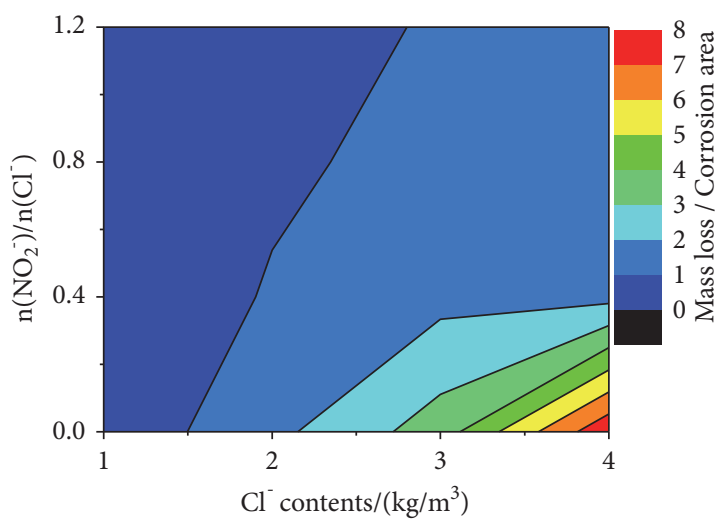

(d)

FIgURE 1: Corrosion parameter of steel bar at 30 cycles.

accelerate the formation of hydration products and reduce the porosity of capillary pores, in order to increase density of specimen and benefits to the raise of the carbonation resistance of specimens. The carbonation depth of mixed $\mathrm{NaNO}_{2}$ specimen is minimum under the dosage of $1.0 \%$; the carbonation depth of concrete is obviously bigger than the carbonation depth of cement mortar for $\mathrm{NaNO}_{2}$.

Secondly, it can be seen in the research [25] that a new hydrated crystallization phase $\mathrm{NO}_{2}$-AFm is produced after the hydration of nitrite-containing cement paste and is evenly distributed. During the carbonation process, $\mathrm{NO}_{2}-\mathrm{AFm}$ redecomposes and generates nitrite ions, diffusing to noncarbonated area. This resulted in a decrease of $\mathrm{NO}_{2}{ }^{-}$concentration in carbonated area and an increase in noncarbonated area.

As can be seen from Figure 4 under carbonation, the nitrite ions uniformly distribute in the cement paste diffuse to the uncarbonated zone due to the migration and concentration of the $\mathrm{N}$ element.

Furthermore, nitrite can effectively inhibit the corrosion of steel bars caused by carbonation. The steel bar with a diameter of $10 \mathrm{~mm}$ and a length of $150 \mathrm{~mm}$ is embedded in a $40 \mathrm{~mm} \times 40 \mathrm{~mm} \times 160 \mathrm{~mm}$ nitrite-containing mortar, which carbonated in a solution of $20^{\circ} \mathrm{C}, 60 \% \mathrm{RH}$, and $10 \% \mathrm{CO}_{2}$ until the phenolphthalein ethanol solution is confirmed to be completely carbonated at a high temperature and accelerated corrosion of steel bars under dry and wet cycling conditions. The results show the higher the $\mathrm{NO}_{2}{ }^{-}$concentration in the mortar, the better the antirust effect of steel bar. When the $\mathrm{NO}_{2}{ }^{-}$concentration in the mortar is about $1.66 \%$ of cement mass, the steel corrosion caused by carbonation is totally inhibited. The critical molar ratio of $\mathrm{n}\left(\mathrm{NO}_{2}{ }^{-}\right) / \mathrm{n}\left(\mathrm{Cl}^{-}\right)$under the combined action of chloride and carbonation is about 3 times that of concrete containing only chloride salt $[26,27]$.

\subsection{Corrosion Inhibition in Existing Reinforced Concrete} Structures. Newly built reinforced concrete structures can improve the rust resistance by increasing the compactness and incorporating corrosion inhibitors when formulating concrete [28-30]. As for existing reinforced concrete structures that are corroding or in corrosive environment, the commonly used method is to treat the protective layer on the concrete surface with large cracks or high chloride salt concentration and fill the mortar containing nitrite components [30-33]. Ann et al. [8] treated the rusted steel bar with mortar containing adsorbent and achieved a certain corrosion-resisting effect. This adsorbent is capable of adsorbing chloride ions in the concrete surrounding the steel bar and releasing nitrite ions. After the treatment, the potential of the repair site increases from $-400 \mathrm{mV}$ to $-450 \mathrm{mV}$ to about $-200 \mathrm{mV}\left(\mathrm{Cu} / \mathrm{CuSO}_{4}\right.$ electrode $)$ in the 

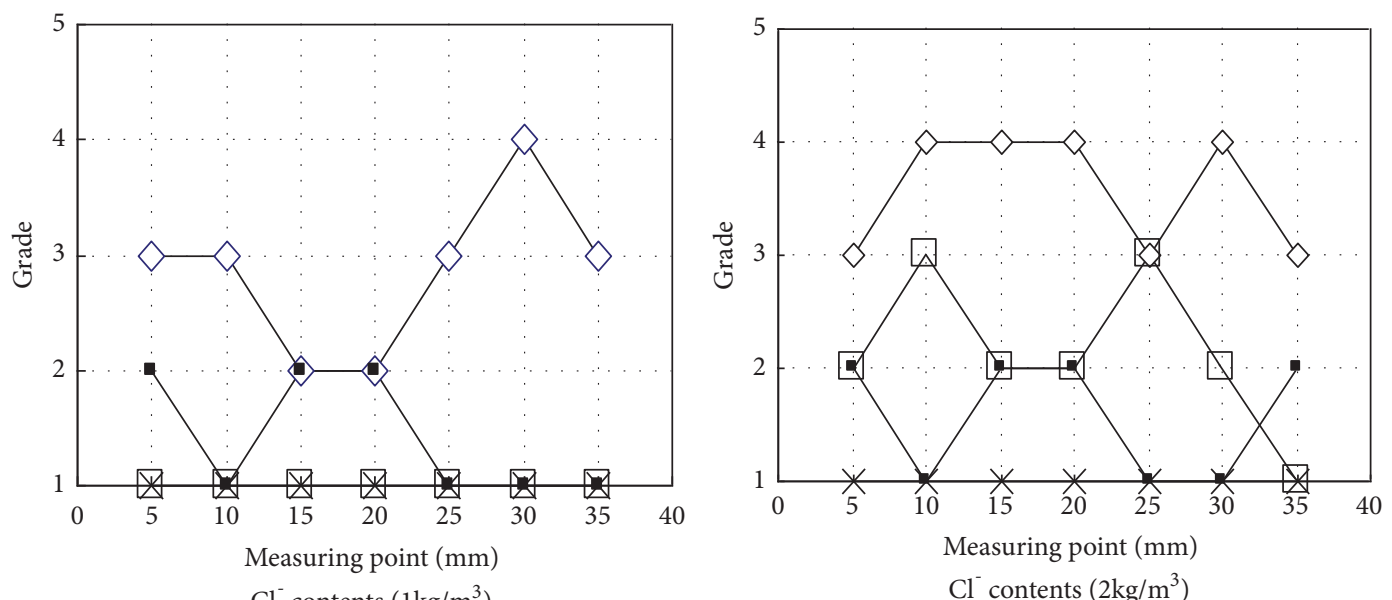

$\mathrm{Cl}^{-}$contents $\left(1 \mathrm{~kg} / \mathrm{m}^{3}\right)$

$$
\begin{array}{ll}
\neg-0 & \square 0.8 \\
\rightarrow-0.4 & \times 1.2
\end{array}
$$

$$
\checkmark-0 \quad \longrightarrow 0.8
$$

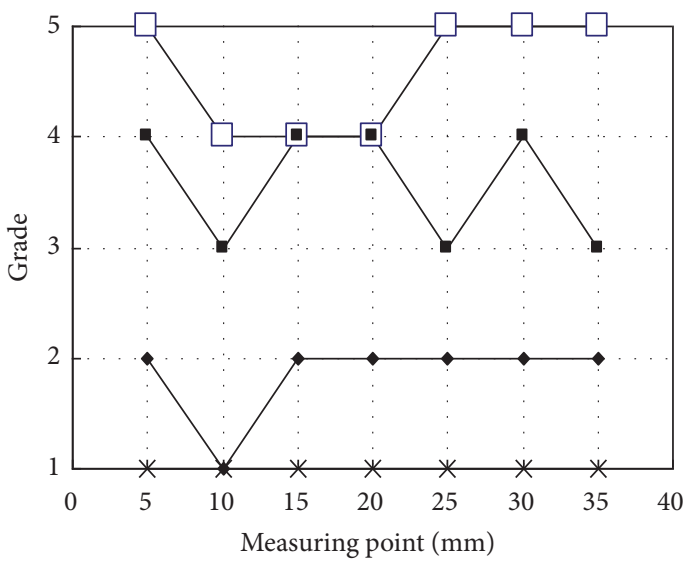

$\mathrm{Cl}^{-}$contents $\left(3 \mathrm{~kg} / \mathrm{m}^{3}\right)$

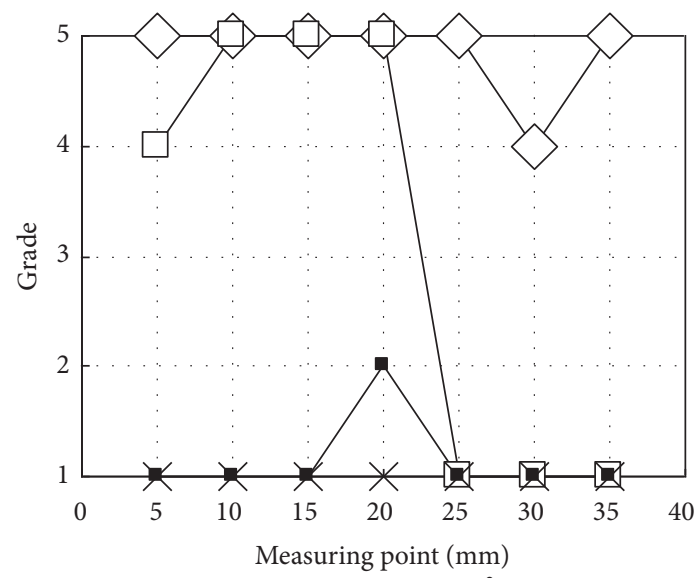

$\mathrm{Cl}^{-}$contents $\left(4 \mathrm{~kg} / \mathrm{m}^{3}\right)$

$$
\begin{array}{llll}
\rightarrow-0 & \rightarrow-0.8 & \multimap-0 & \rightarrow-0.8 \\
-0.4 & \times 1.2 & -\square-0.4 & \rightarrow-1.2
\end{array}
$$

Figure 2: Corrosion grade of steel bar at 30 cycles.

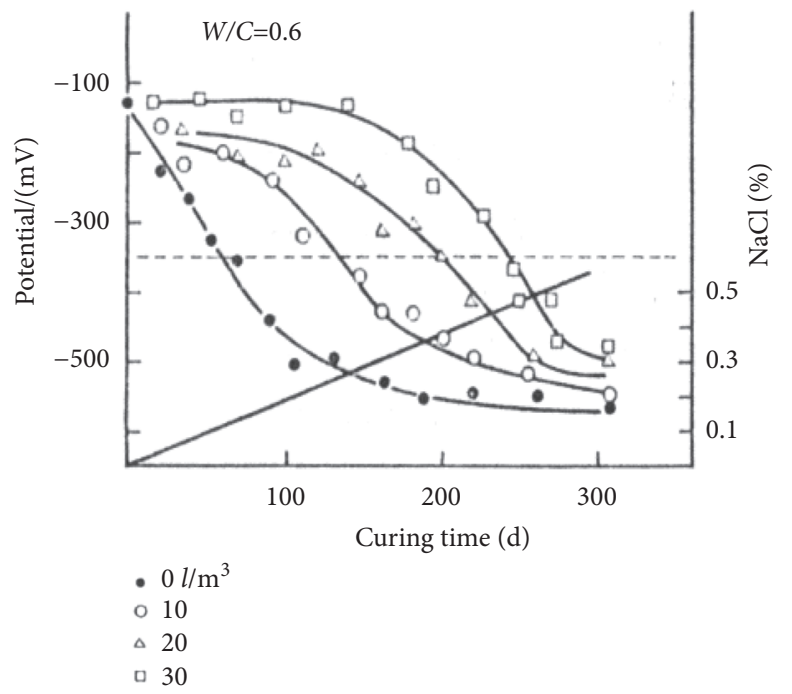

FIgURE 3: Variation of $\mathrm{NaCl}$ concentration and potential. 

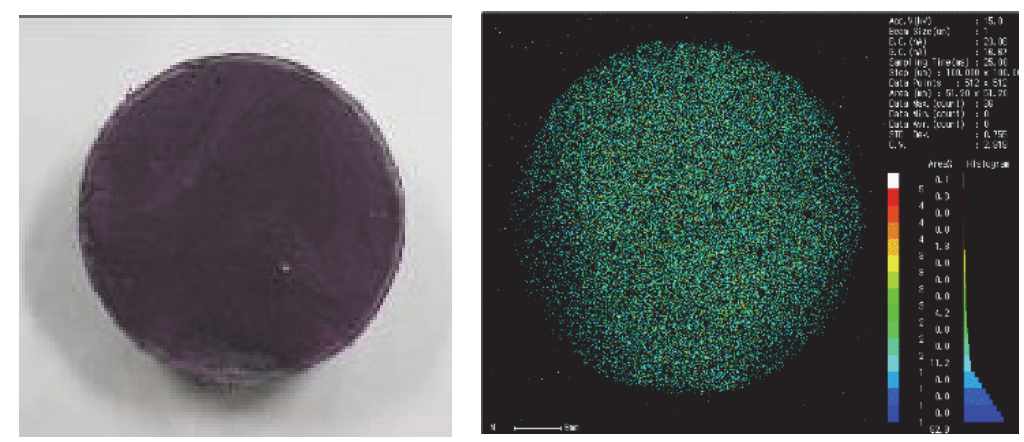

(a) Before carbonation
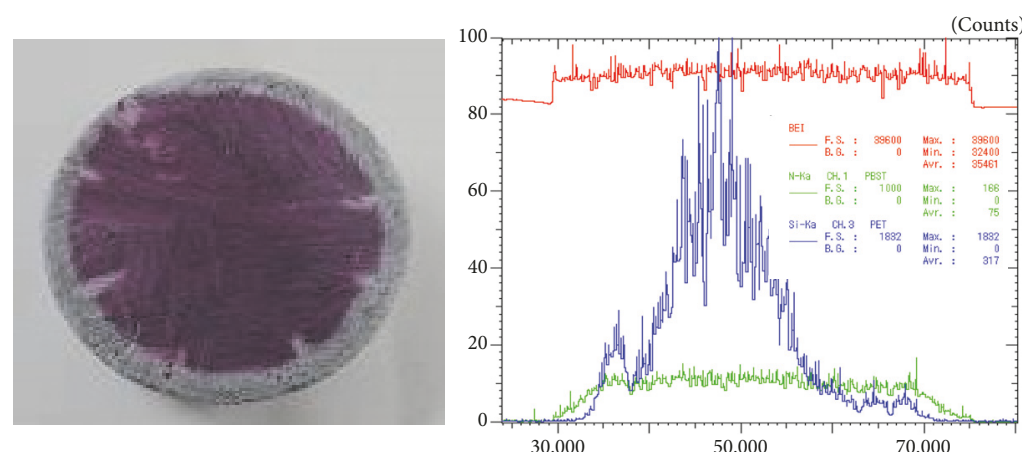

(b) One week of carbonation
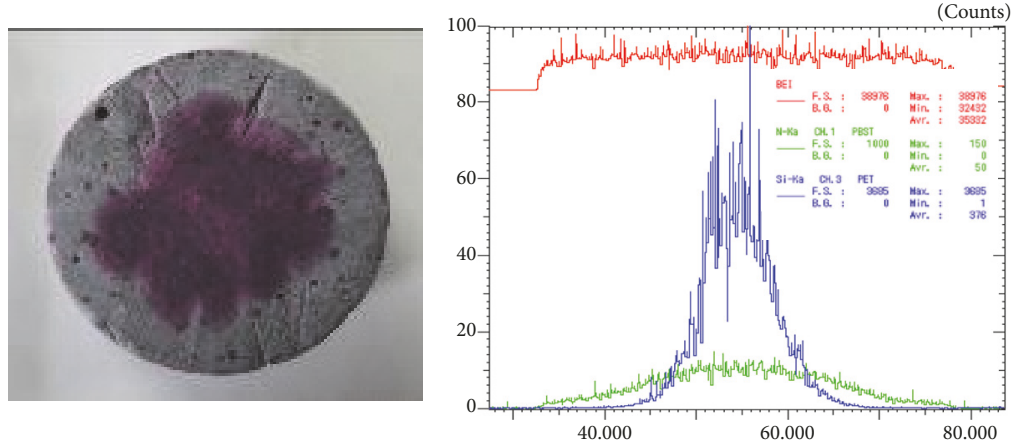

(c) Two weeks of carbonation
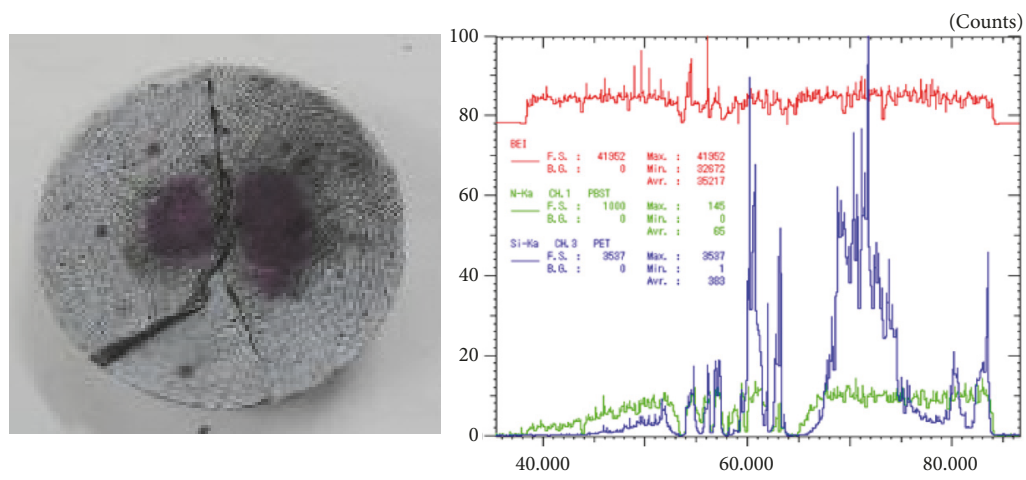

(d) Four weeks of carbonation

FIGURE 4: Distribution of N elements after carbonation. 


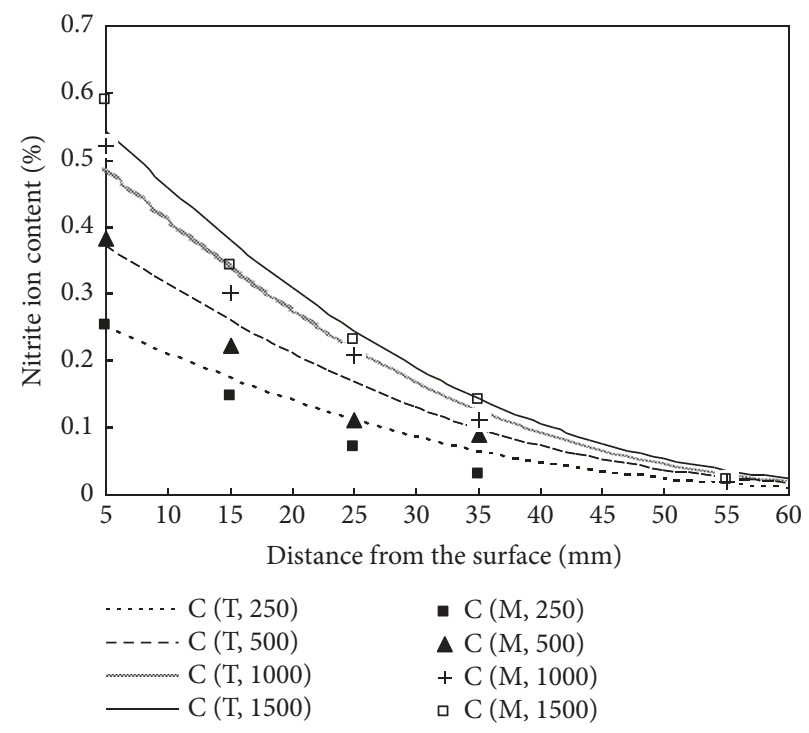

FIGURE 5: Nitrite ion concentration in concrete.

29th month after treatment, but the unrepaired other parts produce different degrees of macro cell corrosion. This is because the corrosive environment of the steel surface after repairing is different; the unrepaired area tends to become the anode of the reinforced magnetic battery and accelerates the corrosion of the macro battery, which does not achieve the expected effect. In addition, if the above method is used, the damage caused to the concrete structures in which the surface of the concrete is not rusted and expanded is too severe. Therefore, the most effective method is to take certain measures to form a blunt environment around the steel bar without destroying the concrete protective layer, so as to achieve the purpose of preventing rust. At present, MCI migration type corrosion inhibitors have appeared at home and abroad, the main components of such corrosion inhibitors are amines, esters, fatty acids, alcohols, and other organic substances; those have certain characteristics of permeation and volatilization and can penetrate into concrete to protect them by adsorption and film formation. This type of corrosion inhibitor is generally harmless to human body, but its effect is not satisfactory, mainly because the rust prevention effect is not obvious. In addition, MCI's longterm effectiveness, testing methods, etc. are also issues for future research, mainly because there are still some different understandings in terms of penetration depth, test indicators, volatilization, and retention time [34-38]. Liang et al. [39] considered that nitrite has better diffusion effects than other inorganic salts such as sodium benzoate, stannous chloride, chromium salt borate, molybdate, and phosphate. In particular, calcium nitrite not only has a strong diffusion capacity, but also has no obvious adverse effect on concrete and the possibility of causing alkali-aggregate reaction. For concrete corrosion caused by seawater, chloride salt admixture or deicing salt, and other external chloride ions, Liu et al. [40] who used Fick's law to predict the concentration distribution of $\mathrm{NO}_{2}{ }^{-}$in concrete applied a certain concentration of calcium nitrite aqueous solution on concrete surface, and the nitrite ions diffused from the outer surface of the concrete to the inside to make the nitrite ion concentration around the steel bar reach the critical $\mathrm{n}\left(\mathrm{NO}_{2}{ }^{-}\right) / \mathrm{n}\left(\mathrm{Cl}^{-}\right)$molar ratio of corrosion inhibition. When $35 \%$ high concentration aqueous calcium nitrite is applied to the concrete surface at $250 \mathrm{~g} / \mathrm{m}^{2}$, $500 \mathrm{~g} / \mathrm{m}^{2}, 1000 \mathrm{~g} / \mathrm{m}^{2}$, and $1500 \mathrm{~g} / \mathrm{m}^{2}$, nitrite is infiltrated into the concrete after 6 months and the ion osmotic concentration is shown in Figure 5, where $M$ is the measured value and $\mathrm{T}$ is the theoretical value, which fully demonstrates that the nitrite ion has excellent diffusion properties. The higher the concentration of the aqueous solution of calcium nitrite, the greater the amount of concrete surface coating, and the greater the concentration of nitrite ions permeating the concrete, which can effectively protect the steel. It is worth noting that when the concentration of nitrite ions diffused to the surface of the steel bar after repair is not uniform, the uneven concentration of the surface of the steel bar and the ratio of the area of the anode and the cathode have a great influence on the corrosion of the steel bar. The research results show that the larger the difference of the concentration of nitrite ions in the surface of the steel in the concrete, the greater the ratio of the area of the anode and the cathode, the more serious the corrosion of the steel.

\subsection{Long-Term Corrosion Inhibition Effect of Nitrite Corrosion} Inhibitor. In the concrete setting and hardening stage, $\mathrm{C}_{3} \mathrm{~A}$ will react with $\mathrm{Cl}^{-}$which accounts for $0.4 \%$ of the cement mass to form Friedel's salt. At the same time, part of $\mathrm{Cl}^{-}$ participates in the electrochemical corrosion reaction of steel bars, which changes the concentration of chloride ions in the pore solution. Similarly, some of the $\mathrm{NO}_{2}{ }^{-}$will be consumed by the reaction with the corrosion products during the electrochemical corrosion process of the steel bars, and part of $\mathrm{NO}_{2}{ }^{-}$will adsorb on the surface of the cement product, causing the concentration of $\mathrm{NO}_{2}{ }^{-}$in the pore solution to change. The changes in the concentration of 
these two ions will affect corrosion inhibition effect of nitrite corrosion inhibitor. The higher the concentration of nitrite, the more obvious the effect of inhibiting corrosion. When the concentration of nitrite is low, the $\mathrm{NO}_{2}{ }^{-}$is totally consumed during the reaction of formula (1), so the corrosion inhibition effect on the steel bar is lost. Therefore, it is necessary to further clarify the changes of free nitrite ion and chloride ion concentration in concrete during corrosion reaction. In addition, the concentration of free chloride and nitrite ions in chloride and nitrite-containing concrete changes greatly during the 28 days of hydration and stabilizes in the later stage, indicating that as long as sufficient critical $\mathrm{n}\left(\mathrm{NO}_{2}{ }^{-}\right) / \mathrm{n}\left(\mathrm{Cl}^{-}\right)$ molar ratio is incorporated into the concrete, the nitrite concentration can ensure the long-term rust inhibition effect of reinforced concrete. The American Concrete Institute ACI also confirmed that it is a long-term effective measure to prevent corrosion of steel bars [41-44].

\section{Methods for Detecting Nitrite Ion Concentration}

5.1. Direct Titration. The 28-day cement mortar specie is cut into pieces with a cutter at intervals of $20 \mathrm{~mm}$. After cleaning the cutting surface, spraying resorcinol and zirconium oxide ion developer, potassium iodide, and starch solution developer on the surface, ion concentration can be judged by observing the color change of different sodium nitrite concentration.

5.2. Semiquantitative Determination of Color Difference. The 28-day cement mortar specie is cut into pieces with a cutter at intervals of $20 \mathrm{~mm}$, and the cut surface is cleaned as a sample of the spray display agent. Mixing 4,4-diphenylmethane diisocyanate with toluene in a ratio of 1:10 by volume is to uniformly prepare isocyanate display solution. After preparing the sample and the display liquid, spraying the isocyanate display solution on the cut sample at a dosage of $80 \mathrm{~g} / \mathrm{m}^{2}$, the sample is dried for 2 hours and then measured with a color difference meter. Compare the color difference between the product under test and the sample plate and output three sets of data of brightness L, chromaticity a, chromaticity b, and color difference $\triangle \mathrm{E}$.

5.3. Spectrophotometric Quantitative Determination. According to the "Cement Chemical Analysis Method" (GB/T1762008), after 7 days of standardization, the cement paste specie is crushed with a steel mill, so place the small pieces in a standard square sieve with a hole diameter of $0.6 \mathrm{~mm}$, $0.3 \mathrm{~mm}$, and $0.15 \mathrm{~mm}$, and then the powder after the $0.15 \mathrm{~mm}$ filter hole is taken out and dried in a dry box. $10 \mathrm{~g}$ of each cement paste dry powder is placed in an Erlenmeyer flask containing $100 \mathrm{ml}$ of water, and the Erlenmeyer flask is placed in a $60^{\circ} \mathrm{C}$ water bath and heated with a glass rod for 10 minutes, after which the Erlenmeyer flask is placed in a shaker and shaken for 10 minutes. Then $10 \mathrm{ml}$ of the solution which is sufficiently heated and shaken separated is extracted and diluted 1000 times, and each diluted solution is placed in a test tube to a designated mark; at last measurement is performed by a spectrophotometer.

The nitrite ion mass concentration in concrete can be measured semiquantitatively, qualitatively, and quantitatively by direct titration, color display, and spectrophotometry, respectively. Li et al. [45] found that the nitrite ion mass concentration measured by spectrophotometry is lower than the actual mixed value, only takes up 30\% 60\% of actual value. Direct titration method is simple, direct, and obvious. The concentration of nitrite in concrete is directly determined by observing, but more influential factors, and cannot be quantitative analysis. Color display method is also more convenient to operate, but only semiquantitative analysis. As for spectrophotometry quantiative analysis, the sensitivity of the method is too high, thus the detection error is unavoidable. All in all, these methods provide a theoretical basis for the effective method to evaluate nitrite ion concentration in concrete.

\section{Environmental Concerns about Nitrite Corrosion Inhibitor}

Nitrite corrosion inhibitor is the earliest, most used, and most effective steel corrosion inhibitor. However, at present, there are some environmental concerns in China. In fact, nitrite does not have skin permeability and volatility, and nitrite poisoning can only occur through ingestion. As an industrial product, its production and use are not related to food. As long as necessary protective measures are taken at every link, the probability of poisoning in the human body is very small. Nitrite has been used as a steel bar corrosion inhibitor for more than 60 years, but no news on the poisoning of nitrite corrosion inhibitor has been reported. Studies have shown that the dissolution rate of nitrite-containing concrete after soaking in water for 10 months is only $0.0041 \%$. It found, what concerns the application does not affect the environmental corrosion inhibitor nitrite in a reinforced concrete structure [46].

\section{Conclusions}

(1) Nitrite is a long-term effective steel bar corrosion inhibitor. Regardless of whether it is carbonation or chloride salt, the corrosion inhibition effect of nitrites in the common steel bar is the most obvious. The reasonable corrosion resistance method should be selected according to the corrosive environment and engineering characteristics.

(2) The greater the content of nitrite in concrete, the more effective the inhibition of steel corrosion. The methods of direct titration, color display, and spectrophotometry can effectively measure the nitrite ion mass concentration in concrete.

(3) The greater the concentration difference of nitrite ions on the surface of the steel in concrete, the greater the ratio of the area of the anode to the cathode, the more severe the corrosion. Due to the toxicity of nitrite, it should be restricted to some extent in some special projects. 


\section{Conflicts of Interest}

The authors declare that there are no conflicts of interest regarding the publication of this paper.

\section{Acknowledgments}

This work was sponsored by the National Natural Science Foundation of China (51778302, 51808300, 51878360), K.C. Wong Magna Fund in Ningbo University, and Natural Science Foundation of Ningbo [No. 2018A610357].

\section{References}

[1] S. Muthulingam and B. Rao, "Non-uniform corrosion states of rebar in concrete under chloride environment," Corrosion Science, vol. 93, pp. 267-282, 2015.

[2] H. S. Wong, Y. X. Zhao, A. R. Karimi, N. R. Buenfeld, and W. L. Jin, "On the penetration of corrosion products from reinforcing steel into concrete due to chloride-induced corrosion," Corrosion Science, vol. 52, no. 7, pp. 2469-2480, 2010.

[3] J. O. Okeniyi, O. A. Omotosho, O. O. Ajayi, and C. A. Loto, "Effect of potassium-chromate and sodium-nitrite on concrete steel-rebar degradation in sulphate and saline media," Construction and Building Materials, vol. 50, pp. 448-456, 2014.

[4] M. B. Valcarce and M. Vázquez, "Carbon steel passivity examined in solutions with a low degree of carbonation: the effect of chloride and nitrite ions," Materials Chemistry and Physics, vol. 115, no. 1, pp. 313-321, 2009.

[5] Y.-B. Gao, J. Hu, Q. Liu et al., "Application and prospects of corrosion inhibitors for reinforcing steel," Journal of Xiamen University (Natural Science), vol. 54, no. 5, pp. 713-720, 2015.

[6] W. Shi, T.-Z. Wang, Z.-H. Dong, and X.-P. Guo, "Application of wire beam electrode technique to investigate the migrating behavior of corrosion inhibitors in mortar," Construction and Building Materials, vol. 134, pp. 167-175, 2017.

[7] M. Balonis, B. Lothenbach, G. L. Saout et al., "Calcium nitrite corrosion inhibitor in portland cement: influence of nitrite on chloride binding and mineralogy," Journal of the American Ceramic Society, vol. 94, no. 7, pp. 2230-2241, 2011.

[8] K. Y. Ann, H. S. Jung, H. S. Kim, S. S. Kim, and H. Y. Moon, "Effect of calcium nitrite-based corrosion inhibitor in preventing corrosion of embedded steel in concrete," Cement and Concrete Research, vol. 36, no. 3, pp. 530-535, 2006.

[9] L. Luo, A. Adriaens, A. Elia, and G. De Schutter, "Influence of corrosion inhibitors on stern-geary constant in simulated cement pore solutions," The Journal of the Chinese Ceramic Society, vol. 42, no. 5, pp. 574-578, 2014.

[10] S. Tang, "Influence of calcium nitrite on passive films of rebar in simulated concrete pore solution," Materials Protection, vol. 50, no. 8, pp. 28-31, 2017.

[11] J. Gonzalez, E. Ramirez, and A. Bautista, "Protection of steel embedded in chloride containing concrete by means of inhibitors," Cement and Concrete Research, vol. 28, no. 4, pp. 577-589, 1998.

[12] N. S. Berke and M. C. Hicks, "Predicting long-term durability of steel reinforced concrete with calcium nitrite corrosion inhibitor," Cement and Concrete Composites, vol. 26, no. 3, pp. 191-198, 2004.

[13] M. Ramasubramanian, B. S. Haran, S. Popova, B. N. Popov, M. F. Petrou, and R. E. White, "Inhibiting action of calcium nitrite on carbon steel repairs," Journal of Materials in Civil Engineering, vol. 13, no. 1, pp. 10-17, 2001.

[14] S. M. Abd El Haleem, S. Abd El Wanees, E. E. Abd El Aal, and A. Diab, "Environmental factors affecting the corrosion behavior of reinforcing steel II. Role of some anions in the initiation and inhibition of pitting corrosion of steel in $\mathrm{Ca}(\mathrm{OH}) 2$ solutions," Corrosion Science, vol. 52, no. 2, pp. 292-302, 2010.

[15] J. M. Ortega, I. Sánchez, and M. Á. Climent, "Impedance spectroscopy study of the effect of environmental conditions on the microstructure development of sustainable fly ash cement mortars," Materials , vol. 10, no. 10, pp. 569-583, 2017.

[16] M.-S. Chen, C.-T. Sun, and J.-F. Yu, "Mechanism of corrosion inhibitor in concrete corrosion -resistant," Concrete, vol. 6, pp. 80-83, 2015.

[17] R. S. Raman and W. Siew, "Role of nitrite addition in chloride stress corrosion cracking of a super duplex stainless steel," Corrosion Science, vol. 52, no. 1, pp. 113-117, 2010.

[18] J.-Z. Liu, Y.-S. Li, and L-H. Lv, "Effect of anti-freezing admixtures on alkali-silica reaction in mortars," Journal of Wuhan University of Technology-Mater. Sci. Ed, vol. 20, no. 2, pp. 8082, 2005.

[19] P. Garcés, P. Saura, E. Zornoza, and C. Andrade, "Influence of $\mathrm{pH}$ on the nitrite corrosion inhibition of reinforcing steel in simulated concrete pore solution," Corrosion Science, vol. 53, no. 12, pp. 3991-4000, 2011.

[20] M. Ormellese, L. Lazzari, S. Goidanich, G. Fumagalli, and A. Brenna, "A study of organic substances as inhibitors for chloride-induced corrosion in concrete," Corrosion Science, vol. 51, no. 12, pp. 2959-2968, 2009.

[21] J.-Z. Liu, F. Xing, Z.-M. He et al., "Critical mole ratios of nitrite and chloride in reinforced concrete," The Journal of the Chinese Ceramic Society, vol. 38, no. 4, pp. 615-620, 2010.

[22] M. Al-Mehthel, S. Al-Dulaijan, S. H. Al-Idi, M. Shameem, M. Ali, and M. Maslehuddin, "Performance of generic and proprietary corrosion inhibitors in chloride-contaminated silica fume cement concrete," Construction and Building Materials, vol. 23, no. 5, pp. 1768-1774, 2009.

[23] P. Montes, T. W. Bremner, and D. H. Lister, "Influence of calcium nitrite inhibitor and crack width on corrosion of steel in high performance concrete subjected to a simulated marine environment," Cement and Concrete Composites, vol. 26, no. 3, pp. 243-253, 2004.

[24] W.-T. Wang, T.-S. He, C. Shi et al., "Effects of inorganic salts on the carbonation resistance of cement mortar," Bulletin of the Chinese Ceramic Society, vol. 32, no. 1, pp. 56-59, 2013.

[25] J.-Z. Liu, Z. X. Li, and Y-H. Dai, "Effect of carbonation on nitrite ion distribution in cement paste," Journal of Jilin University (Engineering and Technology Edition), vol. 4, 2019.

[26] J. Liu, W. Yuan, Z. He, M. Ba et al., "Microstructural evolution of cement under combined effect of carbonation and chloride salt," Acta Materiae Compositae Sinica, vol. 32, no. 5, pp. 15361546, 2015.

[27] P. Marques, A. Costa, and F. Lanata, "Service life of RC structures: Carbonation induced corrosion. Prescriptive vs. performance-based methodologies," Construction and Building Materials, vol. 24, no. 3, pp. 258-265, 2010.

[28] J. Liu, Q. Feng, and Y. Li, "Nitrite protecting reinforcing bars in concrete from corrosion," Journal of the Chinese Ceramic Society, vol. 32, no. 7, pp. 854-857, 2004.

[29] X. Song, Q. Kong, and X. Liu, "Experimental study on chloride threshold levels in OPC," China Civil Engineering Journal, vol. 40, no. 11, pp. 59-63, 2007. 
[30] M. A. G. Tommaselli, N. A. Mariano, and S. E. Kuri, "Effectiveness of corrosion inhibitors in saturated calcium hydroxide solutions acidified by acid rain components," Construction and Building Materials, vol. 23, no. 1, pp. 328-333, 2009.

[31] K. V. Subramaniam and M. Bi, "Investigation of steel corrosion in cracked concrete: Evaluation of macrocell and microcell rates using Tafel polarization response," Corrosion Science, vol. 52, no. 8, pp. 2725-2735, 2010.

[32] R. Álvarez-Bustamante, G. Negrón-Silva, M. Abreu-Quijano et al., "Electrochemical study of 2-mercaptoimidazole as a novel corrosion inhibitor for steels," Electrochimica Acta, vol. 54, no. 23, pp. 5393-5399, 2009.

[33] M. Bello, N. Ochoa, V. Balsamo et al., "Modified cassava starches as corrosion inhibitors of carbon steel: An electrochemical and morphological approach," Carbohydrate Polymers, vol. 82, no. 3, pp. 561-568, 2010.

[34] G. Achary, Y. A. Naik, S. V. Kumar, T. Venkatesha, and B. Sherigara, "An electroactive co-polymer as corrosion inhibitor for steel in sulphuric acid medium," Applied Surface Science, vol. 254, no. 17, pp. 5569-5573, 2008.

[35] M. Sánchez and M. C. Alonso, "Electrochemical chloride removal in reinforced concrete structures: improvement of effectiveness by simultaneous migration of calcium nitrite," Construction and Building Materials, vol. 25, no. 2, pp. 873-878, 2011.

[36] M. M. Mennucci, E. P. Banczek, P. R. P. Rodrigues, and I. Costa, "Evaluation of benzotriazole as corrosion inhibitor for carbon steel in simulated pore solution," Cement \& Concrete Composites, vol. 31, no. 6, pp. 418-424, 2009.

[37] F. Wombacher, U. Maeder, and B. Marazzani, "Aminoalcohol based mixed corrosion inhibitors," Cement and Concrete Composites, vol. 26, no. 3, pp. 209-216, 2004.

[38] Y. Xu, "Migrating corrosion inhibitor - A new development of corrosion inhibitors for steel bar in concrete," Journal of the Chinese Ceramic Society, vol. 30, no. 1, pp. 94-101, 2002.

[39] H. Liang, L. Li, N. Poor, and A. Sagüés, "Nitrite diffusivity in calcium nitrite-admixed hardened concrete," Cement and Concrete Research, vol. 33, no. 1, pp. 139-146, 2003.

[40] J.-Z. Liu, W. Sun, Z.-M. He et al., "Corrosion inhibition of nitrite salt in existing reinforced concrete structures," Journal of The Chinese Ceramic Society, vol. 42, no. 5, pp. 607-612, 2014.

[41] M. Maage, "Service life prediction of existing concrete structures exposed to marine environment," ACI Materials Journal, vol. 93, pp. 602-608, 1996.

[42] A. Królikowski and J. Kuziak, "Impedance study on calcium nitrite as a penetratingcorrosioninhibitor," Electrochimica Acta, vol. 56, no. 23, pp. 7845-7853, 2011.

[43] Z. Y. Liu, C. W. Miao, and W. Sun, "Effect of migratory corrosion inhibitors on the durability of chloride-contaminated rereinforced concrete(II) - Long-term effect, morphological and mechanismic analysis," Journal of the Chinese Ceramic Society, vol. 38, no. 7, pp. 1323-1327, 2010.

[44] M. D. Pritzl, H. Tabatabai, and A. Ghorbanpoor, "Long term chloride profiles in bridge decks treated with penetrating sealer orcorrosion," Construction and Building Materials, vol. 101, pp. 1037-1046, 2015.

[45] X. Li, J. Liu, C. Zheng, Z. He, and M. Ba, "Detection and analysis of nitrite ion mass concentration in concrete," Journal of Shenyang Jianzhu University (Natural Science), vol. 34, no. 2, pp. 303-309, 2018.
[46] C.-S. Huangfu, Q. Shi, Y.-H. Li et al., "Harm-benefit analysis of nitrite relative to human health," International Journal of Environment and Health, vol. 27, no. 8, pp. 733-736, 2010. 


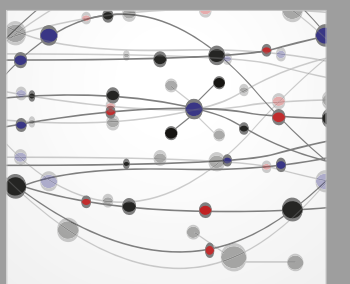

The Scientific World Journal
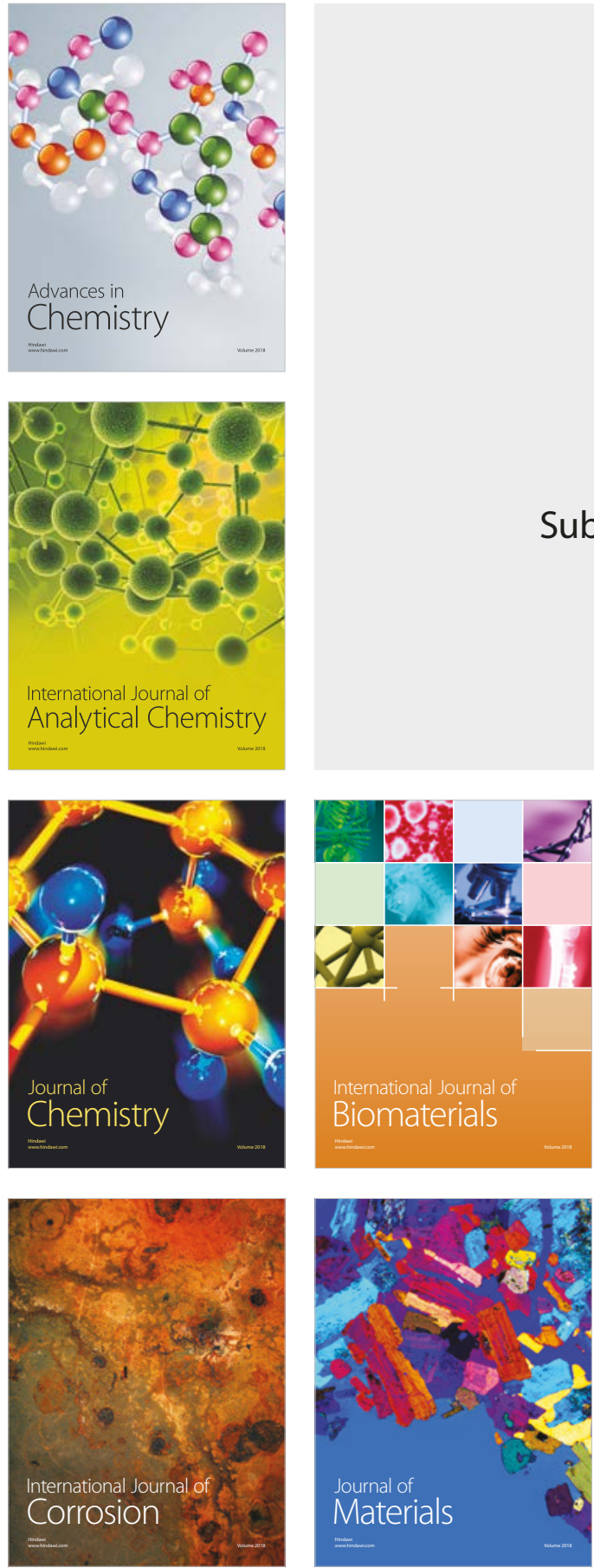

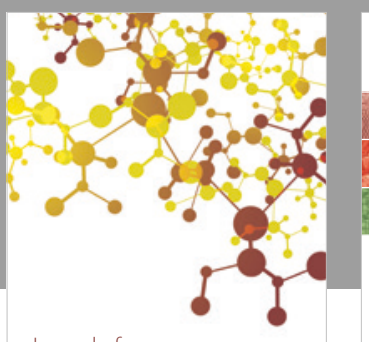

Journal of

Applied Chemistry
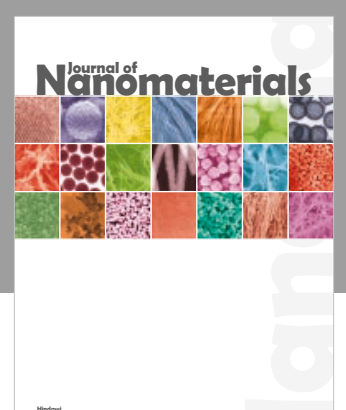

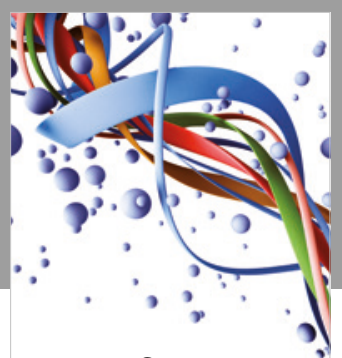

Scientifica

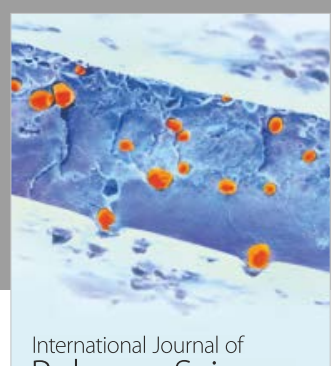

Polymer Science

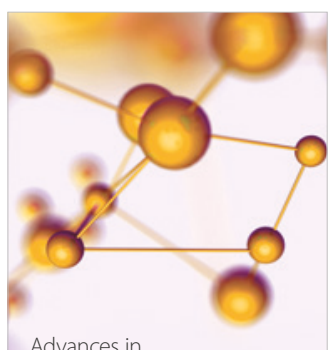

Physical Chemistry
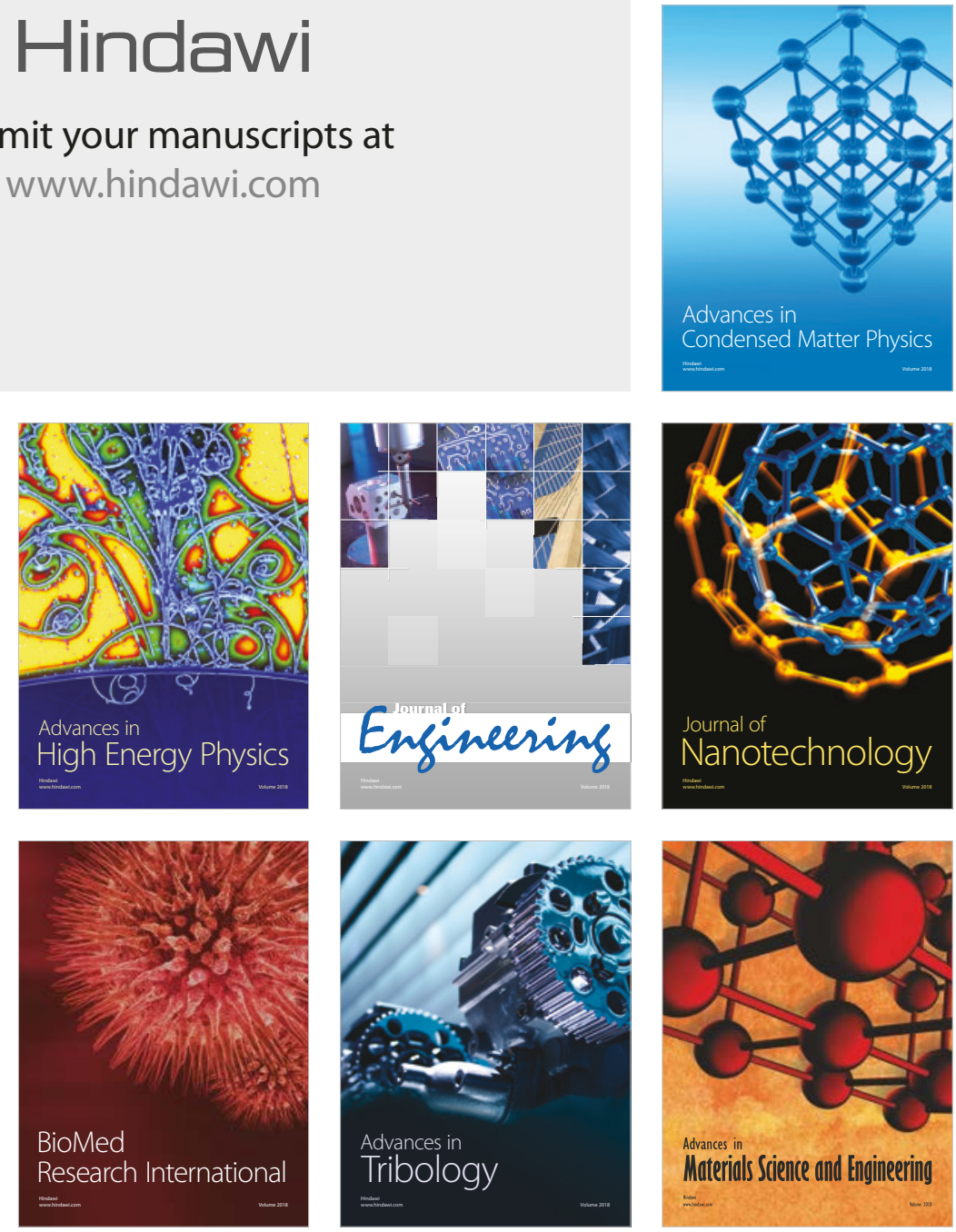